\title{
Trwałość teowych połączeń spawanych wykonanych ze stali S355 przy cyklicznym zginaniu ze skręcaniem z uwzględnieniem obróbki cieplnej
}

\author{
Durability of T-welded joints made of S355 steel under cyclic \\ bending with torsion taking into account the heat treatment
}

\section{Streszczenie}

W pracy przedstawiono wyniki badań trwałości, inicjacji oraz wzrostu pęknięć zmęczeniowych próbek ze stali S355 z pachwinowymi spoinami $w$ dwóch wariantach lica spoin (wklęsłych oraz wypukłych), poddanych zginaniu ze skręcaniem. Badania przeprowadzono przy stałej wartości współczynnika asymetrii cyklu $R=-1$. W zaprezentowanych wynikach uwzględniono wpływ obróbki cieplnej na trwałości badanych próbek.

Słowa kluczowe: spawanie; zginanie ze skręcaniem; wzrost pęknięć zmęczeniowych; struktura; spoiny pachwinowe

\section{Abstract}

The paper presents the test results of lifetime, initiation and fatigue crack growth of specimens, from steel S355 with fillet welds in two variants of the welds face (concave and convex), subjected to bending with torsion. The tests were carried out at a constant value of stress ratio $R=-1$. The results presented included the influence of heat treatment on lifetime of the specimens tested.

Keywords: welding; bending with torsion; fatigue crack growth; structure; fillet welds

\section{Wstęp}

Prowadzone przez autorów badania trwałości teowych połączeń spawanych ze spoinami pachwinowymi mają swoje źródła w ciągle aktualnych problemach pojawiania się pęknięć w elementach pracujących urządzeń i konstrukcji. W przemyśle górniczym, zgodnie z przepisami [1], prowadzone są obowiązkowe, okresowe badania (w tym nieniszczące) poszczególnych elementów urządzeń, których współczynniki bezpieczeństwa nie mogą ulec obniżeniu. Do takich urządzeń zalicza się głównie: wirniki wentylatorów np. WPK pracujących w stacjach wentylatorów głównego przewietrzania (rys. 1a), kół i bębnów pędnych maszyn wyciągowych, elementów dźwigniowych układów hamulcowych maszyn wyciągowych (rys. 1b) oraz kół linowych i odciskowych (rys. 1c) [2,3].

Celem tej pracy jest przedstawienie wyników badań trwałości, inicjacji oraz wzrostu pęknięć zmęczeniowych próbek ze spoinami pachwinowymi (bez jak i po obróbce cieplnej), wykonanych ze stali S355, poddanych cyklicznemu zginaniu ze skręcaniem.
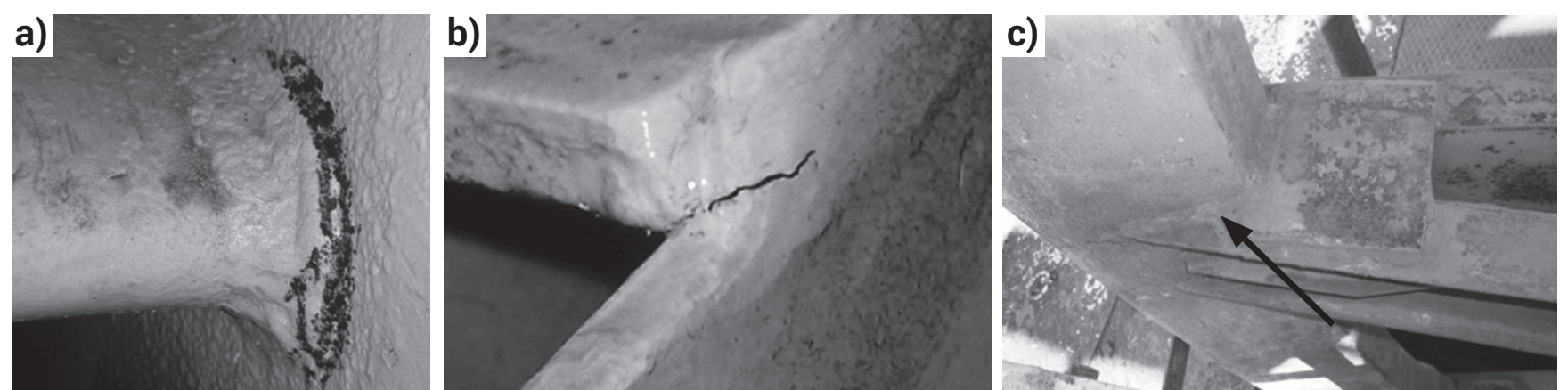

Rys. 1. Wadliwe złącze spawane: a) łopaty wirnika wentylatora, b) dźwigni układu hamulcowego maszyny wyciągowej, c) koła linowego Fig. 1. Faulty welded joint of: a) fan rotor blade, b) hoist machine brake system, c) rope wheel

Mgr inż. Janusz Lewandowski; dr hab. inż. Dariusz Rozumek, prof. PO - Politechnika Opolska.

Autor korespondencyjny/Corresponding author. janusz210@wp.pl 


\section{Badania doświadczalne}

Do badań doświadczalnych użyto próbki wykonane ze stali S355. Podstawowe właściwości chemiczne i wytrzymałościowe użytego materiału przedstawiono w tablicy I. Materiałem wyjściowym był pręt ciągniony o średnicy $\emptyset 30 \mathrm{~mm}$, z którego wykonano elementy próbek połączone poprzez spawanie metodą TIG w osłonie argonu. Otrzymano w ten sposób próbki z teowymi złączami spawanymi (spoiny pachwinowe), w dwóch wariantach lica spoin.

Kształty i wymiary próbek spawanych (z wklęsłymi oraz wypukłymi spoinami) pokazano na rysunku 2. Badania doświadczalne wykonano na próbkach spawanych bez obróbki cieplnej oraz na próbkach poddanych dwóm rodzajom obróbki cieplnej.

Pierwsza obróbka cieplna wykonana została poprzez poddanie próbek wyżarzaniu odprężającemu w temperaturze $630^{\circ} \mathrm{C}$ przez 2 godziny. Natomiast druga obróbka cieplna polegała na wyżarzaniu normalizującym w temperaturze $940^{\circ} \mathrm{C}$ przez 1 godzinę. W celu wyeliminowania wadliwych próbek mogących wpłynąć na ostateczny wynik badań zmęczeniowych, wszystkie próbki zostały poddane badaniom nieniszczącym metodą magnetyczno-proszkową (MT) w świetle UV. Badania doświadczalne wykonano z zastosowaniem maszyny zmęczeniowej typu MZGS-100 [4], przy stałej amplitudzie momentu $M_{a}=9,20 \mathrm{~N} \cdot \mathrm{m}$, przy współczynniku asymetrii cyklu $R=-1$ z częstotliwością obciążenia $28,4 \mathrm{~Hz}$. Przyrosty długości pęknięć obserwowano oraz mierzono na bocznych powierzchniach próbek za pomocą mikrometru cyfrowego umieszczonego w mikroskopie przenośnym o powiększeniu 25x z dokładnością $0,01 \mathrm{~mm}$ oraz notowano liczbę wykonanych cykli obciążenia $\mathrm{N}$.

\section{Wyniki badań $\mathrm{i}$ ich analiza}

Wszystkie próbki spawane poddano pomiarom twardości metodą Vickersa HV0,1 zgodnie z PN-EN 1043-1 [5]. Wyniki uśrednionych pomiarów twardości próbek bez obróbki cieplnej i po obróbce przedstawiono na rysunku 3. Można zauważyć, że próbki bez OC, zwłaszcza w strefie wpływu ciepła,
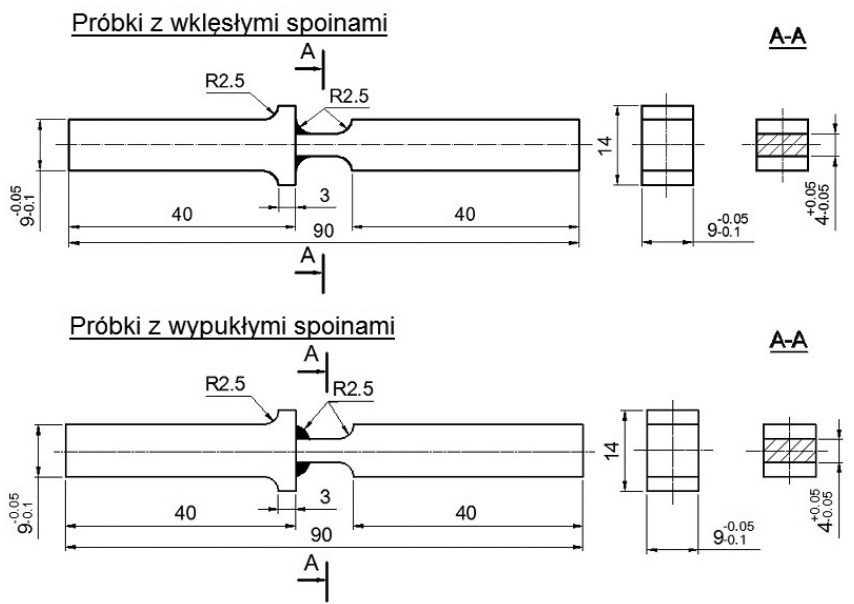

$\underline{A-A}$

Rys. 2. Próbki z pachwinowym spoinami: a) wklęsłymi, b) wypukłymi Fig. 2. Specimens with fillet welds: a) concave, b) convex

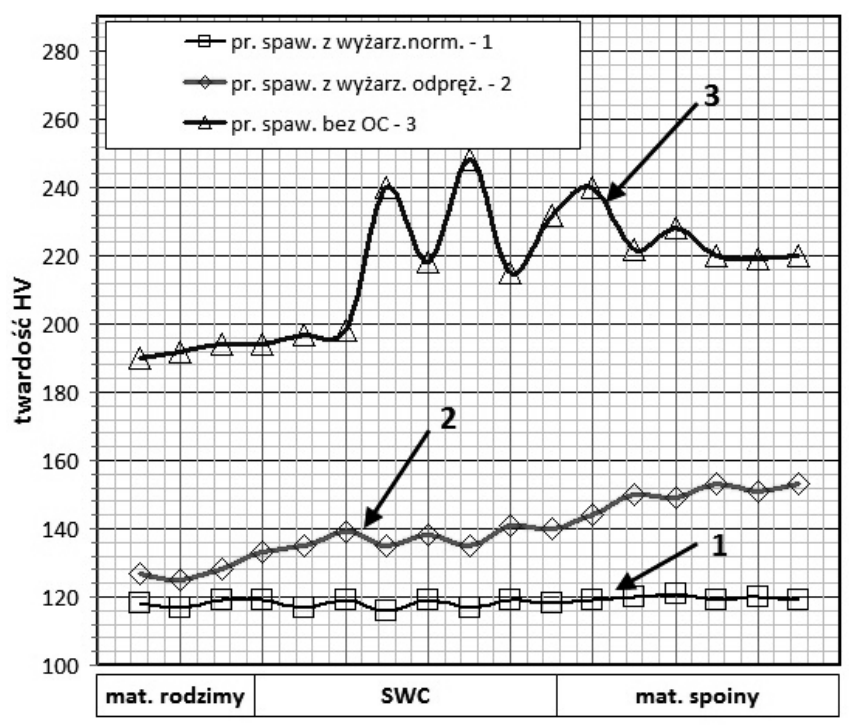

Rys. 3. Pomiary twardości z podziałem na strefy

Fig. 3. Hardness measurements with division into zones

miały najwyższą twardość, lecz obserwuje się znaczne zróżnicowanie wartości. W próbkach poddanych wyżarzaniu odprężającemu twardości były mniejsze od twardości próbek bez OC, a rozkład twardości był bardziej równomierny. Najmniejszą twardość stwierdzono w próbkach poddanych wyżarzaniu normalizującemu.

Na podstawie wykonanych serii badań (po 3 próbki na każdym poziomie) otrzymano wykresy obrazujące inicjację oraz kolejne przyrosty długości pęknięć zmęczeniowych (aż do zniszczenia próbek) w funkcji liczby cykli dla próbek ze spoinami wklęsłymi i wypukłymi poddanych obróbce cieplnej i bez niej (rys. 4). Na rysunku 4a można zauważyć, że dla próbek ze spoinami wklęsłymi największe trwałości zmęczeniowe posiadały próbki bez OC. Ich zniszczenie następowało przy wykonanej liczbie cykli 56000 z rozrzutem wyników do $8 \%$ (dla trzech zbadanych próbek). Próbki poddane wyżarzaniu odprężającemu wykazywały mniejsze trwałości, a ich zniszczenie następowało przy liczbie cykli 23000 z rozrzutem wyników do $9 \%$. Najmniejsze trwałości zmęczeniowe otrzymano dla próbek po wyżarzaniu normalizującym, które przy liczbie 11000 cykli ulegały zniszczeniu z rozrzutem wyników do $9 \%$.

$\mathrm{Na}$ rysunku 4b przedstawiono wyniki badań próbek ze spoinami wypukłymi. Można zauważyć, że tak jak w przypadku spoin wklęsłych, największe trwałości zmęczeniowe posiadały próbki bez obróbki cieplnej, a ich zniszczenie następowało przy wykonanej liczbie cykli 55000 z rozrzutem wyników do $8 \%$. Mniejsze trwałości osiągały próbki poddane wyżarzaniu odprężającemu, gdzie ich zniszczenie następowało przy liczbie cykli 21000 z rozrzutem wyników do 9\%. Natomiast najmniejsze trwałości zmęczeniowe wykazywały próbki po wyżarzaniu normalizującym podobnie jak dla spoin wklęsłych, które uległy zniszczeniu przy liczbie cykli 5700 z rozrzutem wyników do $9 \%$.

Z przedstawionych wyników badań można zauważyć, że niezależnie od kształtu lica spoiny, próbki poddane obróbce cieplnej wykazywały spadek trwałości zmęczeniowej. Spadek trwałości zmęczeniowej dla próbek ze spoinami

Tablica I. Podstawowe właściwości chemiczne i wytrzymałościowe stali S355

Table I. Chemical composition and mechanical properties of S355 steel

\begin{tabular}{|c|c|c|c|c|c|c|c|c|c|c|c|c|c|c|}
\hline \multicolumn{7}{|c|}{ Skład chemiczny stali $\boldsymbol{w}[\%]$} & \multicolumn{5}{c|}{ Właściwości wytrzymałościowe } \\
\hline $\mathrm{C}$ & $\mathrm{Mn}$ & $\mathrm{Si}$ & $\mathrm{P}$ & $\mathrm{S}$ & $\mathrm{Cr}$ & $\mathrm{Ni}$ & $\mathrm{Cu}$ & $\mathrm{Fe}$ & $\mathrm{R}_{\mathrm{e}}[\mathrm{MPa}]$ & $\mathrm{R}_{\mathrm{m}}[\mathrm{MPa}]$ & $\mathrm{A}_{10}[\%]$ & $\mathrm{Z}[\%]$ & $\mathrm{E}[\mathrm{GPa}]$ & $v$ \\
\hline 0,2 & 1,49 & 0,33 & 0,023 & 0,024 & 0,01 & 0,01 & 0,035 & reszta & 357 & 535 & 21 & 50 & 210 & 0,30 \\
\hline
\end{tabular}


a)

Próbki z wklęsłymi spoinami Stal \$355 $\mathrm{M}_{\mathrm{a}}=9.2 \mathrm{~N} \cdot \mathrm{m} R=-1$

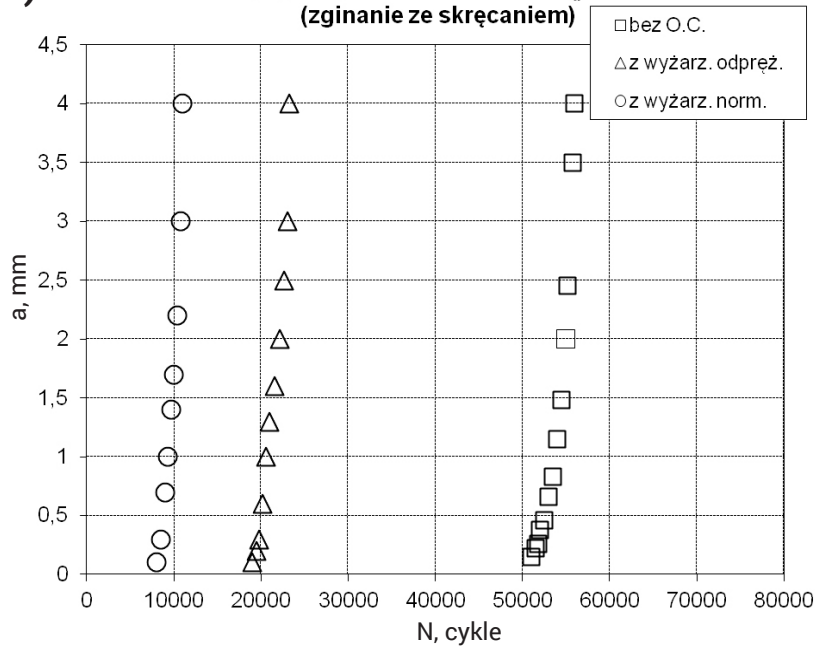

b) Próbki z wypuklymi spoinami Stal $\$ 355 M_{a}=9.2 \mathrm{~N} \cdot \mathrm{m} R=-1$

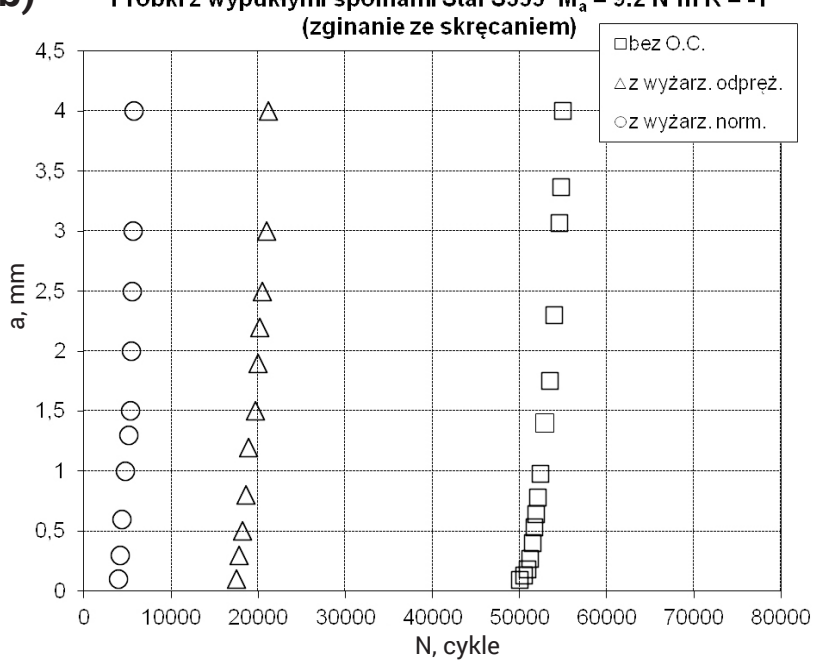

Rys. 4. Długości pęknięć zmęczeniowych w funkcji liczby cykli przy zginaniu ze skręcaniem dla próbek: a) ze spoinami wklęsłymi, b) ze spoinami wypukłymi

Fig. 4. Fatigue crack length vs. number of cycles under bending with torsion for specimens with: a) concave welds, b) convex welds

wklęsłymi i wyżarzonych odprężająco wyniósł 59\% w porównaniu do próbek bez obróbki cieplnej. Natomiast spadek trwałości próbek wyżarzonych normalizująco wyniósł $80 \%$ w porównaniu do próbek bez OC. Różnice w trwałościach zmęczeniowych próbek ze spoinami wypukłymi i wklęsłymi były zbliżone. Analizując dalej wyniki badań, autorzy zauważyli, że zmiany strukturalne zachodzące w badanym materiale, w wyniku przeprowadzonych obróbek cieplnych, wpływają na obniżenie trwałości zmęczeniowych. Mikrostruktura stali S355 (materiału rodzimego) [2] charakteryzuje się drobnoziarnistą strukturą ferrytyczno-perlityczną wykazującą drobne równoosiowe ziarna ferrytu oraz bardzo drobny perlit w układzie pasmowym.

$\mathrm{Na}$ rysunku 5 przedstawiono mikrostrukturę materiału próbki spawanej poddanej wyżarzaniu odprężającemu. W strefie wpływu ciepła występuje gruboziarnista struktura bainitu oraz wysokoodpuszczonego martenzytu. Główne pęknięcie przebiega poza spoiną oraz pierwotną SWC w obszarze próbki o strukturze wysokoodpuszczonego martenzytu. Od pęknięcia głównego rozwijały się liczne pęknięcia boczne inicjowane w obszarach bogatych w wydzielenia węglików.
Mikrostrukturę materiału próbki spawanej poddanej wyżarzaniu normalizującemu pokazano na rysunku 6 . W przypadku wyżarzania normalizującego w spoinie i SWC wytworzyła się struktura ferrytu z niewielką ilością perlitu, co stanowi główną przyczynę obniżenia trwałości zmęczeniowych badanych próbek.

Propagacja pęknięcia głównego przebiegała poza spoiną w jednorodnej strukturze ferrytyczno-perlitycznej strefy SWC. Występują również pęknięcia boczne propagujące po granicach ziaren. W obrębie złomu obserwuje się pękanie mieszane: kruche i plastyczne z obszarami dużych odkształceń plastycznych. Biorąc pod uwagę wyniki badań, należy z dużą ostrożnością podejść do obróbki cieplnej złączy spawanych remontowanych, głównie w warunkach warsztatowych, urządzeń górniczych. Niewłaściwe jej przeprowadzenie może w konsekwencji doprowadzić do niebezpiecznych zdarzeń.

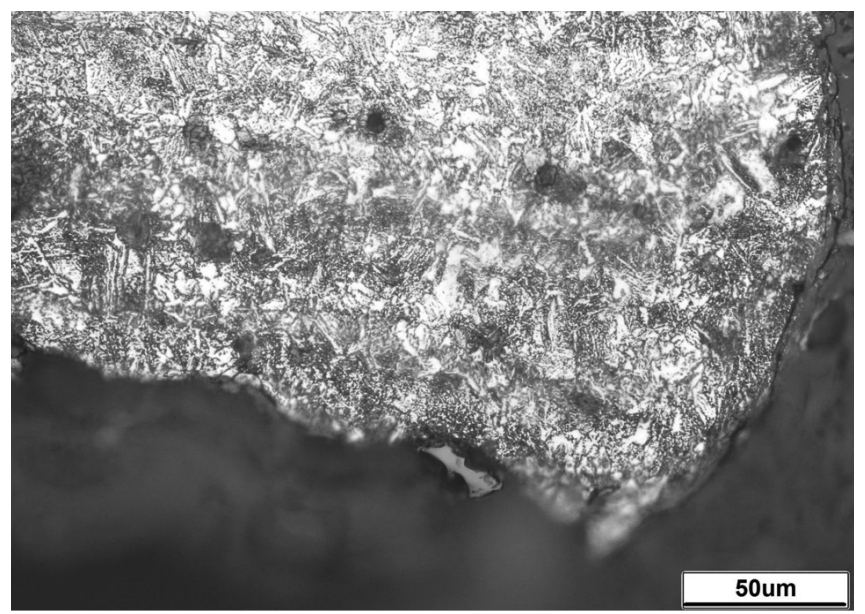

Rys. 5. Mikrostruktura próbki spawanej po wyżarzaniu odprężającym (powiększenie 500x), struktura bainitu oraz wysokoodpuszczonego martenzytu i rozwój wtórnych pęknięć

Fig. 5. Microstructure of the welded specimen after relief annealing (500x magnification), bainite and sorbitol structure and the development of secondary cracks

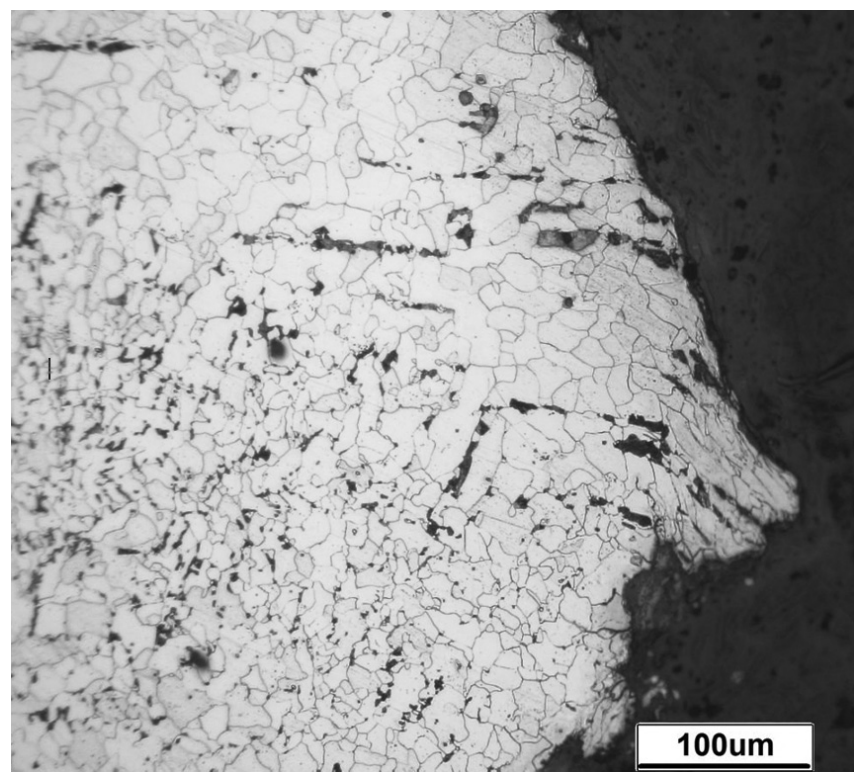

Rys. 6. Mikrostruktura próbki spawanej po wyżarzaniu normalizującym (powiększenie 200x), ferryt z niewielką ilością perlitu

Fig. 6. Microstructure of the welded specimen after normalizing annealing (magnification 200x), ferrite with a small amount of pearlite 


\section{Podsumowanie}

Na podstawie przeprowadzonych badań połączeń spawanych poddanych cyklicznemu zginaniu ze skręcaniem można stwierdzić, że inicjacja pęknięć zmęczeniowych we wszystkich badanych próbkach rozpoczynała się z jednej strony i w strefie wpływu ciepła. Próbki bez obróbki cieplnej charakteryzowały się największą trwałością, przy czym nieznacznie większą trwałość miały próbki ze spoinami wklęsłymi. Największą twardość materiału zmierzono w SWC na próbkach bez obróbki cieplnej, a najmniejszą w próbkach po wyżarzaniu normalizującym, co jest związane z większą plastycznością złączy po obróbce.

\section{Literatura}

[1] Rozporządzenie Ministra Energii z dnia 23 listopada 2016 r. w sprawie szczegółowych wymagań dotyczących prowadzenia ruchu podziemnych zakładów górniczych (Dz. U. 2017 poz. 1118).

[2] Lewandowski J., Rozumek D., Hepner M.: Badania połączeń spawanych poddanych wahadłowemu zginaniu, Przegląd Spawalnictwa, Warszawa, Vol. 88, 4/2016, s. 23-26.

[3] Lewandowski J., Rozumek D.: Cracks growth in S355 steel under cyclic bending with fillet welded joint, Theoretical and Applied Fracture Mechanics, Vol. 86, 2016, pp. 342-350.

[4] Rozumek D., Macha E.: Opis rozwoju pęknięć zmęczeniowych w materiałach sprężysto-plastycznych przy proporcjonalnym zginaniu ze skręcaniem, Politechnika Opolska, Opole 2006, s. 196.

[5] PN-EN 1043-1:2000 Spawalnictwo - Badania niszczące metalowych złączy spawanych - Próba twardości - Próba twardości złączy spawanych łukowo. 